\title{
PHYSICAL AND ELECTRICAL PROPERTIES OF YTTRIA-STABILIZED ZIRCONIA THIN FILMS PREPARED BY RADIO FREQUENCY MAGNETRON SPUTTERING
}

\author{
Dmitriy A. Golosov*, Sergey M. Zavatskiy, Sergey N. Melnikov \\ Thin Film Research Laboratory, Belarusian State University of Informatics and Radioelectronics, Minsk, \\ Belarus \\ * corresponding author: dmgolosov@gmail.com
}

ABstraCt. This paper presents the electrophysical characteristics of a 7 mol.\% yttria-stabilized zirconia (YSZ) thin film deposited by radio-frequency magnetron sputtering. In order to form the crystalline structure, the deposited films were annealed in air over a temperature range of $700 \div 900{ }^{\circ} \mathrm{C}$. By XRD analysis it was established that as the deposited films were amorphous, they crystallized into a pure cubic structure as a result of annealing in air at a temperature above $820^{\circ} \mathrm{C}$.

The electrophysical properties of YSZ films were investigated on structures such as Ni/YSZ/Pt/Ti/Si and Ni/YSZ/Si. Film features $\varepsilon>20$ and $\operatorname{tg} \delta<0.05$ were obtained. An estimate of the capacity-voltage characteristic proved that the Ni/YSZ/Si structures possessed a hysteresis. This hysteresis resulted from the drift of the mobile ions in the YSZ film.

High-temperature ionic conductivity of the stabilized zirconia was determined by the measurements of the electric resistivity of the YSZ films at $1 \mathrm{kHz}$ over the temperature range from ambient to $800^{\circ} \mathrm{C}$. The YSZ film conductivity obtained was $1.96 \times 10^{-2} \mathrm{~S} / \mathrm{cm}$ under $800^{\circ} \mathrm{C}$.

KEYWORDs: yttria-stabilized zirconia, RF sputtering, X-ray diffraction, dielectric constant, loss tangent, capacity-voltage characteristic, ionic conductivity.

\section{INTRODUCTION}

Yttria-stabilized zirconia (YSZ) is recognized as a very attractive electrical insulator because it is characterized by high chemical stability, resistivity, and relative dielectric constant. In microelectronics, films of stabilized zirconia are used as buffer layers, preventing the functional layers from interacting chemically with silicon, in particular, in high-temperature superconductors [2, 8]. Today these films are widely applied as gate dielectrics in field-effect transistors and dynamic random-access memories (DRAM) [15, 11], and also as an insulator in silicon-on-insulator structures [7, 5].

Doped zirconia has ionic transport properties under high temperatures, and thus can be used as a solid electrolyte in micro solid-oxide fuel cells (MSOFC) [3, 13, 10, or as sensitivity elements in integrated gas sensors (GS) 4, 14. For these devices, the thickness of the solid electrolyte layer must not exceed $1 \div 2 \mu \mathrm{m}$ in order to reduce ohmic loss and decrease the operating temperatures down to $500 \div 600{ }^{\circ} \mathrm{C}$ [6]. The requirements imposed on the solid electrolyte are rather tough: it has to be mechanically strong and chemically reliable at high temperatures, mechanically and chemically stable in time, should have maximal ionic and minimal electronic conductivity, and also be gasproof.

The aim is therefore to obtain and study the properties of doped zirconia films grown by plasma de- position methods [1]. RF magnetron sputtering, unlike other techniques, enables dense uniform films to be deposited under comparatively low temperatures; features stability of the process, the possibility of standalone control of the deposition parameters, and supports deposition over large-area substrates 9 . However, the electrophysical properties of RF sputtered doped zirconia thin films need further study.

In the present paper, the authors report the synthesis of YSZ thin films by RF magnetron sputtering and report the results of studying the structural and electrical properties of YSZ films.

\section{EXPERIMENT}

Figure 1 illustrates our experimental installation for thin-film YSZ deposition by RF magnetron sputtering. The installation is based on the Leybold-Heraeus A550 VZK exhaust cart. The vacuum chamber is equipped with an external flanged Hall current ion source. It is used for substrate pre-cleaning. The originally designed RIF.039.001 magnetron sputtering system with a $\varnothing 39 \mathrm{~mm}$ target was used to sputter a ceramic $\mathrm{ZrO}_{2}+7 \mathrm{~mol} . \% \mathrm{Y}_{2} \mathrm{O}_{3}$ target. The magnetron was mounted in the place of the target unit in the ion source. A $13.56 \mathrm{MHz}$ RF power source having $1300 \mathrm{~W}$ in the maximal power output, was used as the power supply.

Monocrystalline superalloyed silicon Si (100), and structures of $\mathrm{Si}_{3} \mathrm{~N}_{4}(1 \mu \mathrm{m}) / \mathrm{Si}, \quad \mathrm{Pt} \quad(150 \mathrm{~nm}) / \mathrm{Ti}$ 


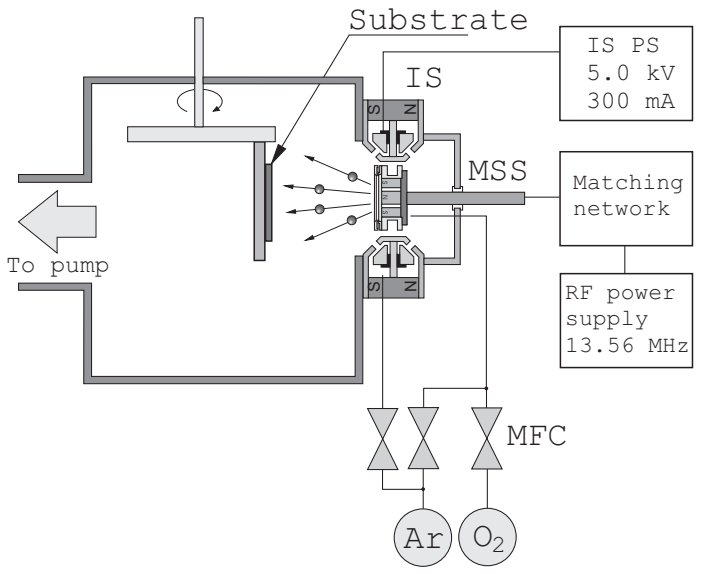

FiguRE 1. Experimental installation for deposition of thin-film doped zirconia by RF magnetron sputtering: MSS - magnetron sputtering system, IS - ion source, MFC - mass flow controller.

$(100 \mathrm{~nm}) / \mathrm{Si}$ were used as substrates. In the series of experiments, the substrates were mounted in a rotating substrate holder. The vacuum chamber was pumped down to a residual pressure of $8 \times 10^{-4} \mathrm{~Pa}$. The substrates were pre-cleaned with an ion beam. For this purpose, Ar was added into the gas distribution system of the ion source at the flow rate $Q_{\mathrm{Ar}}=10 \mathrm{sccm}$. During all the experiments the cleaning time, ion energies and discharge currents were constant, at $3 \mathrm{~min}$, $700 \mathrm{eV}$, and $40 \mathrm{~mA}$, respectively.

Then the targets were cleaned of impurities, for which the substrates were taken away from the deposition zone, and the working gases were supplied directly into the magnetron discharge zone $\left(\mathrm{Ar} / \mathrm{O}_{2}\right.$ mixture). The argon flow rate was $Q_{\mathrm{Ar}}=50 \mathrm{sccm}$, while the oxygen flow rate was $Q_{\mathrm{O}_{2}}=10 \mathrm{sccm}$. The target cleaning modes for all the experiments were constant: forward power $P_{\mathrm{F}}=70 \mathrm{~W}$, reflected power $P_{\mathrm{R}}=5 \mathrm{~W}$, and sputtering time of $20 \mathrm{~min}$.

Then the substrates were placed into the deposition zone. The total gas flow rate was kept constant at a level of $60 \mathrm{sccm}$. The oxygen content in the gas mixture was varied from 0 to $30 \%$, whereas the pressure in the chamber was maintained at $0.2 \mathrm{~Pa}$. The discharge power stabilization mode with $125 \mathrm{~W}$ and $80 \mathrm{~W}$ in the forward power was used for thin-film deposition, while the level of the reflected power did not exceed $10 \%$ of the forward power. The deposition time in all the experiments was kept constant at $180 \mathrm{~min}$. The substrate was placed $82 \mathrm{~mm}$ away from the target surface. The thickness of the deposited films varied within $200 \div 400 \mathrm{~nm}$, depending on the oxygen content in the $\mathrm{Ar} / \mathrm{O}_{2}$ gas mixture.

Then the deposited films were annealed in air, using the Isoprin IR heating system. The annealing temperature varied within the temperature range of $700 \div 900{ }^{\circ} \mathrm{C}$ (annealing time $15 \mathrm{~min}$ ).

The phase composition of the YSZ films was determined by means of the X-ray diffraction (XRD) method, using the DRON-3 system in $\mathrm{CuK} \alpha$ radiation.

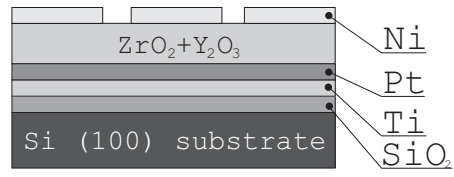

Figure 2. Ni/YSZ/Pt capacitor stucture.

The X-ray patterns were obtained at a rate of $60 \% \mathrm{~h}$ in the angular range of $2 \theta=20 \div 80^{\circ}$, and room temperature. The thickness of the deposited layers was determined with the POI-O8 optical interferometric profilometer. The capacitor structures (Fig. 2) were formed to measure the electrophysical characteristics of the YSZ films. The doped zirconia thin film $(200 \div 400 \mathrm{~nm}$ in thickness $)$ was deposited onto superalloyed silicon $\mathrm{Si}$ (100) and Pt/Ti/Si structures, followed by film annealing. The upper Ni electrode was deposited by ion-beam sputtering through a mask. The capacitors obtained were $0.8 \times 0.8 \mathrm{~mm}$.

The capacitance, the dielectric loss tangent, and the $\mathrm{C}-\mathrm{V}$ characteristics were obtained using the LCR meter E7-20 at frequencies between $25 \mathrm{~Hz}$ and $1.0 \mathrm{MHz}$. The dielectric constant values were calculated on the basis of the thickness and capacitance of the YSZ layer, using the formula $\varepsilon=C d / \varepsilon_{0} S$, where $\varepsilon_{0}=8.85 \times 10^{-12} \mathrm{~F} / \mathrm{m}$, and $S$ is the capacitor area $S=6.4 \times 10^{-7} \mathrm{~m}^{2}$. The ionic conductivity of the stabilized zirconia was determined through measurements of the YSZ film electric resistance at $1 \mathrm{kHz}$ and over the temperature range from room temperature up to $800^{\circ} \mathrm{C}$.

\section{RESULts}

We aimed to show how the RF magnetron sputtering conditions of $\mathrm{ZrO}_{2}+7 \% \mathrm{Y}_{2} \mathrm{O}_{3}$ target affect the deposition rate. The deposition rate vs. discharge power and vs. $\mathrm{Ar} / \mathrm{O}_{2}$ producer gas mixture curves were plotted in Fig. 3 The deposition rate decreased practically linearly as the oxygen content in the $\mathrm{Ar} / \mathrm{O}_{2}$ gas mixture was raised, and the discharge power dropped. When the oxygen content in the $\mathrm{Ar} / \mathrm{O}_{2}$ gas mixture was increased to $5 \div 7 \%$, the deposition rate was observed to drop by $20 \div 25 \%$. The estimated sputtering coefficient for the $\mathrm{ZrO}_{2}+7 \% \mathrm{Y}_{2} \mathrm{O}_{3}$ target was $Y_{\text {YSZ }}=0.17$.

The dependence of the phase composition in the YSZ films on the annealing temperature was studied, with $\mathrm{Si}_{3} \mathrm{~N}_{4} / \mathrm{Si}$ (100) structures used as substrates. A silicon nitride layer $1 \mu \mathrm{m}$ in thickness was formed on the surface of the monocrystalline silicon by the CVD method. Yttria-stabilized zirconia thin films were deposited up to a thickness of more than $500 \mathrm{~nm}$ under the following conditions: forward power $125 \mathrm{~W}$, reflected power $10 \mathrm{~W}, Q_{\mathrm{Ar}}=35 \mathrm{sccm}$, $Q_{\mathrm{O}_{2}}=25 \mathrm{sccm}$. Then the samples were annealed in air over the temperature range of $700 \div 900{ }^{\circ} \mathrm{C}$, for $15 \mathrm{~min}$. $\mathrm{XRD}$ was used to analyze the positions and the intensity of the peaks in the respective zirconia phases 


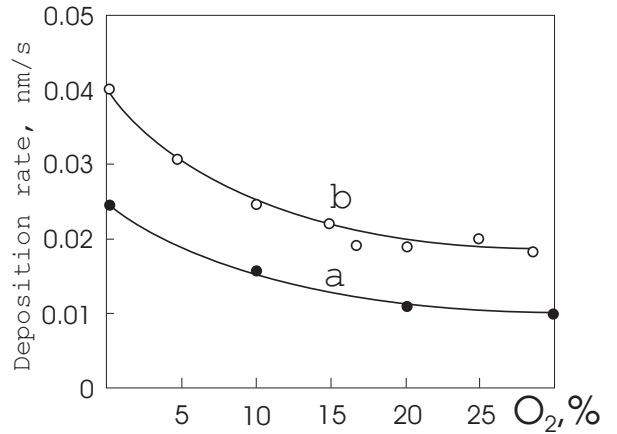

FiguRE 3. YSZ film deposition rate as a function of oxygen percentage in the $\mathrm{Ar} / \mathrm{O}_{2}$ gas mixture at various forward power values: $\mathrm{a}-80 \mathrm{~W}, \mathrm{~b}-125 \mathrm{~W}$.

(Fig. 4). It was determined that regardless of the deposition conditions, wide implicit peaks with a high noise level were present in the X-ray diagrams of the asdeposited films, implying that originally the films were almost non-crystalline and/or amorphous (Fig. 4a). The positions of the peaks corresponded to the monoclinic modification of the crystalline structure. Annealing at temperatures up to $800^{\circ} \mathrm{C}$ resulted in an increase $(-111)$ and $(022)$ in the peak intensity of the monoclinic modification of the crystal lattice, and evoked cubic lattice peaks (Fig. 4 b, c). The peak positions in the films annealed at temperatures above $820^{\circ} \mathrm{C}$ corresponded to the pure cubic modification of the crystal lattice. (111), (200), (220), (311), and (400) cubic peaks with preferable orientation (200) were observed (Fig. 4 d).

The frequency curves for the dielectric constant and the dielectric loss tangent in YSZ films were obtained. Figures 5 and 6 plot the dielectric constant and the loss tangent curves of the deposited YSZ films in Ni/YSZ/Pt and Ni/YSZ/Si structures. The following thin-film YSZ deposition conditions were applied: forward power $125 \mathrm{~W}$, reflected power $11 \mathrm{~W}, Q_{\mathrm{Ar}}=50 \mathrm{sccm}, Q_{\mathrm{O}_{2}}=10 \mathrm{sccm}$. The dielectric constant $\varepsilon=6.0$ and the loss tangent $\operatorname{tg} \delta=0.11$ were observed at $1 \mathrm{MHz}$ of frequency for the deposited films in $\mathrm{Ni} / \mathrm{YSZ} / \mathrm{Pt}$ structures, whereas $\varepsilon=13.2$, $\operatorname{tg} \delta=0.4$ were observed at $1 \mathrm{kHz}$ of frequency, respectively. Ni/YSZ/Si structures exhibited dielectric constant $\varepsilon=6.0$ and the loss tangent $\operatorname{tg} \delta=0.06$ at $1 \mathrm{MHz}$, and $\varepsilon=6.8$ and $\operatorname{tg} \delta=0.34$ at $1 \mathrm{kHz}$, respectively. At frequencies below $500 \mathrm{~Hz}$, the capacitor structures were characterized by high values of dielectric loss and electric conductivity.

As a result of annealing in air under a temperature exceeding $820^{\circ} \mathrm{C}$ as the YSZ cubic structure was formed, the dielectric constant of the films increased, whereas the loss tangent dropped. Figures 7 and 8 plot the dielectric constant and loss tangent curves for $\mathrm{Ni} / \mathrm{YSZ} / \mathrm{Pt}$ and $\mathrm{Ni} / \mathrm{YSZ} / \mathrm{Si}$ structures annealed in air at a temperature of $850{ }^{\circ} \mathrm{C}$ (annealing time 15 min). The YSZ films deposited on the Pt electrode demonstrate a dielectric constant such as $\varepsilon>20$ and loss tangent $\operatorname{tg} \delta<0.05$ in $25 \mathrm{~Hz} \div 1.0 \mathrm{MHz}$ frequency

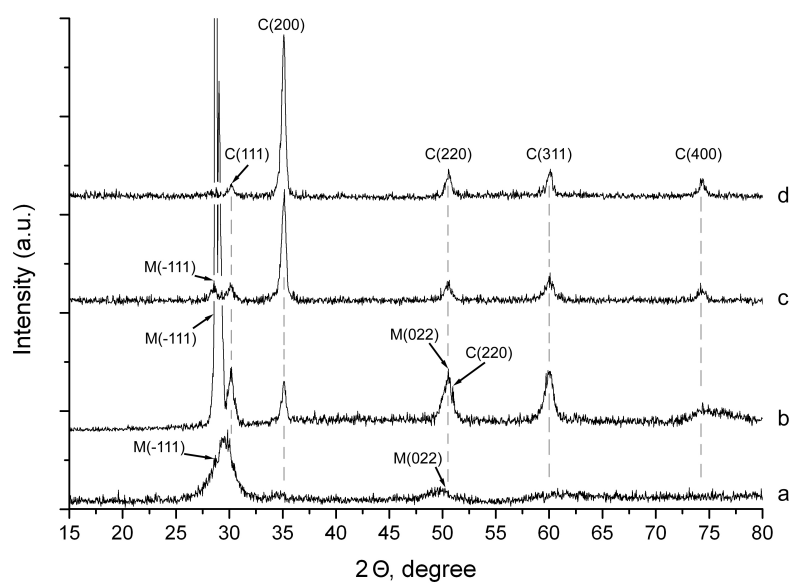

FiguRE 4. XRD patterns of the YSZ films annealed at different temperatures: a - as-deposited, $\mathrm{b}-700{ }^{\circ} \mathrm{C}$, $\mathrm{c}-800^{\circ} \mathrm{C}, \mathrm{d}-900^{\circ} \mathrm{C}$ (annealing time $15 \mathrm{~min}$ ).

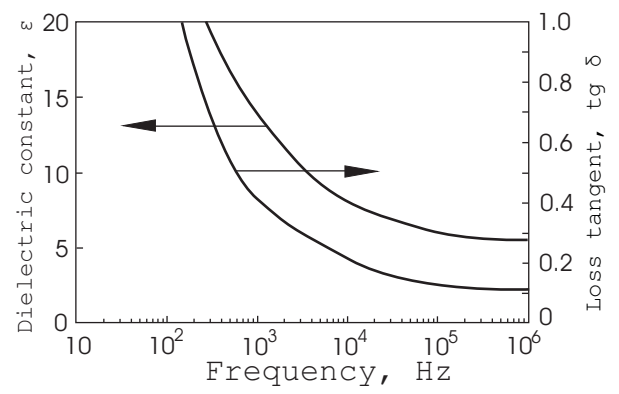

FiguRE 5. Dielectric constant and loss tangent vs. frequency curves for as-deposited YSZ films in $\mathrm{Ni} / \mathrm{YSZ} / \mathrm{Pt}$ structures.

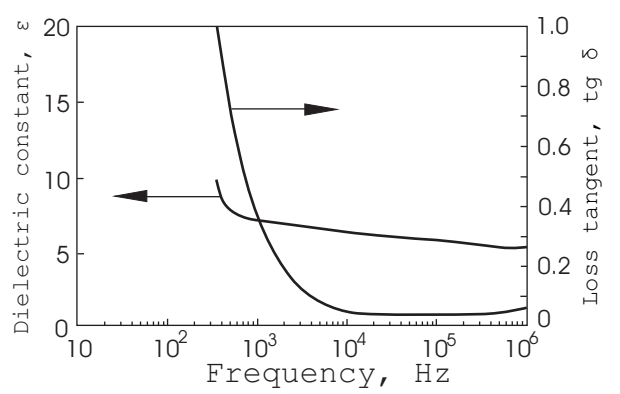

Figure 6. Dielectric constant and loss tangent vs. frequency curves for as-deposited YSZ films in Ni/YSZ/Si structures.

range. YSZ films deposited on an Si substrate in that frequency range showed the dielectric constant as low as $\varepsilon=13 \div 15$ and loss tangent $\operatorname{tg} \delta=0.04 \div 0.1$.

The $\mathrm{C}-\mathrm{V}$ relationships for $\mathrm{Ni} / \mathrm{YSZ} / \mathrm{Pt}$ and $\mathrm{Ni} / \mathrm{YSZ} / \mathrm{Si}$ capacitor structures annealed at $850^{\circ} \mathrm{C}$ were received at DC bias up to $\pm 10 \mathrm{~V}$ (Fig. 9). It was established that the capacitance of $\mathrm{Ni} / \mathrm{YSZ} / \mathrm{Pt}$ structures did not depend on the bias voltage, which was typical for conventional dielectrics. As for the Ni/YSZ/Si structures, estimates of the capacitance-voltage relationships proved that these structures had hysteresis (Fig. 9b). Capacitance variation at DC bias is typical of metal-insulator-semicon- 


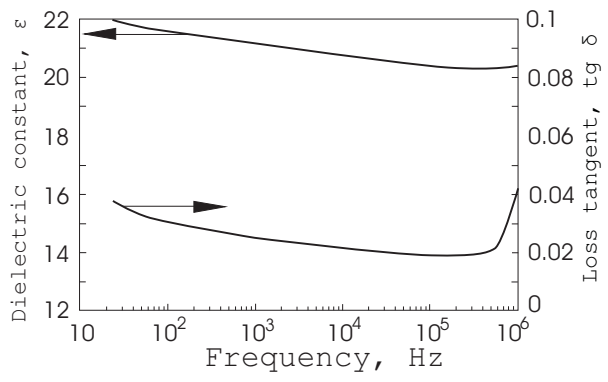

FiguRE 7. Dielectric constant and loss tangent vs. frequency curves for Ni/YSZ/Pt structures annealed in air at $850^{\circ} \mathrm{C}$ (annealing time $15 \mathrm{~min}$ ).

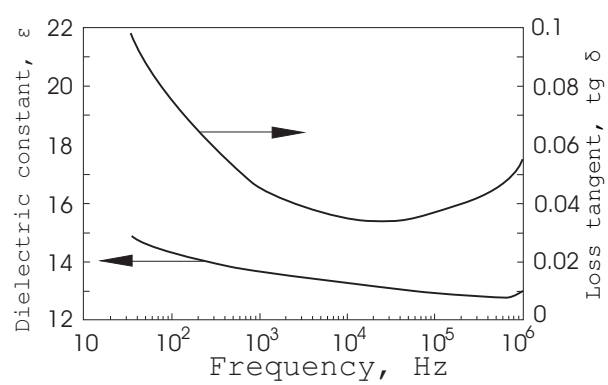

Figure 8. Dielectric constant and loss tangent vs. frequency curves of $\mathrm{Ni} / \mathrm{YSZ} / \mathrm{Si}$ structures annealed in air at $850^{\circ} \mathrm{C}$ (annealing time $15 \mathrm{~min}$ ).
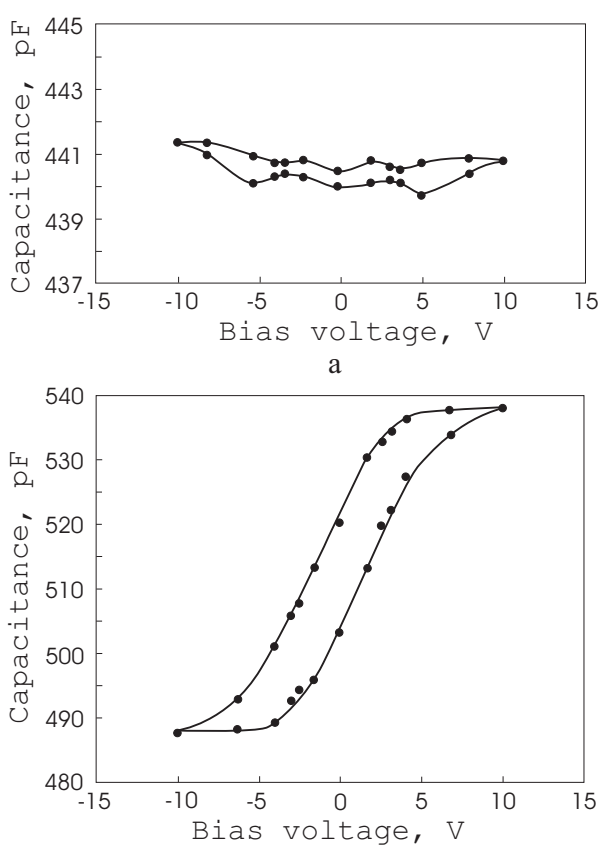

b

FigURE 9. C-V characteristics of structures such as $\mathrm{Ni} / \mathrm{YSZ} / \mathrm{Pt}$ (a) and Ni/YSZ/Si (b) annealed in air at $850^{\circ} \mathrm{C}$ (annealing time $15 \mathrm{~min}$ ).

ductor structures and can account for the charge carrier drift at the YSZ/Si boundary affected by the electric field. The measured $\mathrm{P}-\mathrm{E}$ characteristics of the YSZ layers showed the absence of dielectric polarization, proving that the deposited YSZ films can be referred to as linear dielectrics.

The high-temperature ionic conductivity of the sta-

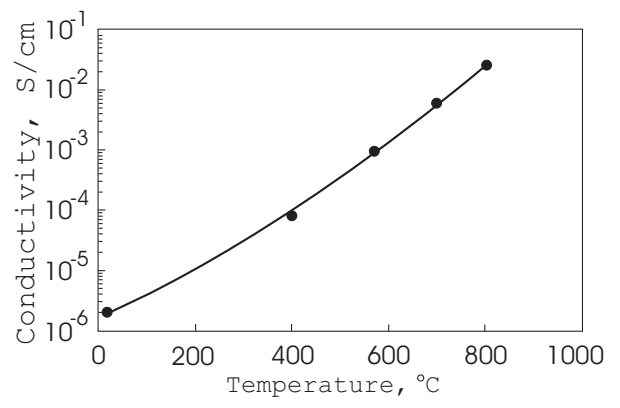

Figure 10. Ionic conductivity the YSZ films in $\mathrm{Ni} / \mathrm{YSZ} / \mathrm{Pt}$ structures annealed in air at $850{ }^{\circ} \mathrm{C}$ (annealing time $15 \mathrm{~min}$ ) as a function of temperature $(f=1.0 \mathrm{kHz})$.

bilized zirconia was determined by measuring the electric resistance of the $\mathrm{Ni} / \mathrm{YSZ} / \mathrm{Pt}$ capacitor structures annealed at $850^{\circ} \mathrm{C}$ at $1 \mathrm{kHz}$ of frequency with the temperature varied from ambient up to $800^{\circ} \mathrm{C}$. It was established that as the temperature was increased, the film conductivity was also grown in proportion to the temperature. When the substrate temperature was $800^{\circ} \mathrm{C}$, the ionic conductivity of the YSZ films reached $0.0196 \mathrm{~S} / \mathrm{cm}$ (Fig. 10). For comparison: the ion conductivity of the bulk YSZ samples is about $0.025 \mathrm{~S} / \mathrm{cm}$ at $800{ }^{\circ} \mathrm{C}[12$.

\section{Conclusion}

The RF magnetron sputtering method was used to deposit thin-film 7 mol.\%-yttria-stabilized zirconia. By means of XRD analysis, it was established that the deposited films were amorphous, they could crystallize into pure cubic structures after being annealed in air under temperatures above $820^{\circ} \mathrm{C}$. The annealing treatment of YSZ films at temperatures above $700{ }^{\circ} \mathrm{C}$ causes the dielectric constant to rise, and the dielectric loss tangent to go down. The films that are obtained are characterized by $\varepsilon>20$ and $\operatorname{tg} \delta<0.05$. Estimates of the capacitance-voltage relationships proved that the $\mathrm{Ni} / \mathrm{YSZ} / \mathrm{Si}$ structures have hysteresis, resulting from the drift of the mobile ions in the YSZ film. It was discovered that the high-temperature ionic conductivity of thin-film YSZ to the temperature and reached $0.0196 \mathrm{~S} / \mathrm{cm}$ with the substrate temperature of $800^{\circ} \mathrm{C}$. Thus, annealed YSZ films can be used as electrical insulators at room temperature, and as an efficient ion conductor of high temperatures.

\section{REFERENCES}

[1] J. W. Bae, et al. Characterization of yttria-stabilized zirconia thin films prepared by radio frequency magnetron sputtering for a combustion control oxygen sensor. Journal of the Electrochemical Society 147(6):2380-2384, 2000.

[2] A. Barda, et al. Initial stages of epitaxial growth of Y-stabilized $\mathrm{ZrO}_{2}$ thin films on $\mathrm{a}^{-\mathrm{SiO}_{x}} / \mathrm{Si}(001)$ substrates. Appl Phys 75(6):2902-2910, 1994.

[3] D. Beckel, et al. Thin films for micro solid oxide fuel cells. Journal of Power Sources 173:325-345, 2007. 
[4] A. Dubbe. Fundamentals of solid state ionic micro gas sensors. Sensors and Actuators B 88:138-148, 2003.

[5] M. Hartmanova, et al. Characterization of ceria/yttria stabilized zirconia grown on silicon substrate. Thin Solid Films 345:330-337, 1999.

[6] J. Van Herle, et al. Concept and technology of SOFC for electric vehicles. Solid State Ionics 132:333-342, 2000 .

[7] T. Koch, P. Ziemann. Effects of ion-beam-assisted deposition on the growth of zirconia films. Thin Solid Films 303:122-127, 1997.

[8] L. Mechin, et al. Double $\mathrm{CeO}_{2} / \mathrm{YSZ}$ buffer layer for the epitaxial growth of $\mathrm{YBa}_{2} \mathrm{Cu}_{3} \mathrm{O}_{7-\delta}$ films on $\mathrm{Si}(001)$ substrates. Physica C: Superconductivity and Applications 269(1-2):124-130, 1996.

[9] L. R. Pederson, P. Singh, Zhou X.-D. Review. Application of vacuum deposition methods to solid oxide fuel cells. Vacuum 80:1066-1083, 2006.
[10] L. R. Pederson, P. Singh, X.-D. Zhou. Application of vacuum deposition methods to solid oxide fuel cells. Review. Vacuum 80:1066-1083, 2006.

[11] K. Sasaki, et al. Limited reaction growth of YSZ $\left(\mathrm{ZrO}_{2}: \mathrm{Y}_{2} \mathrm{O}_{3}\right)$ thin films for gate insulator. Vacuum 66:403-408, 2002.

[12] S.C. Singhal. High-temperature Solid Oxide Fuel Cells: Fundamentals, Design and Applications. Elsevier Science, Oxford, 2003.

[13] J. Will, et al. Fabrication of thin electrolytes for second-generation solid oxide fuel cells. Solid State Ionics 131:79-96, 2000.

[14] S. Yu, et al. Development of a silicon-based yttria-stabilized-zirconia (YSZ), amperometric oxygen sensor. Sensors Actuators B 85:212-218, 2002.

[15] J. Zhu, Z.G. Liu. Dielectric properties of YSZ high- $k$ thin films fabricated at low temperature by pulsed laser deposition. Materials Letters 57(26-27):4297-4301, 2003. 